\title{
Obituaries
}

\section{JOHN WALFORD MCLEAN OBE}

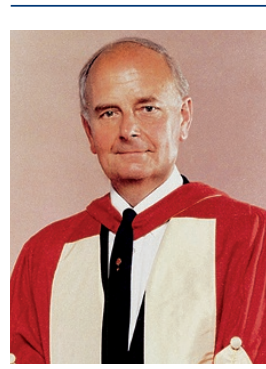

The loss of a former, highly revered leader of the profession is cause for great sadness. John McLean, who died peacefully at home on 29 June 2009, led the profession as President of the BDA (1994/95) and as a great innovator in applied dental materials science in the UK.

John McLean's name will be forever linked to groundbreaking developments in high strength dental ceramics and, in particular, to the introduction of glass-ionomer cements, not to forget his seminal work on the bonding of resins to remaining tooth tissues. John was a giant on whose shoulders many scaled to great heights, but to most he was an icon amongst fellow practitioners - a champion of excellence in clinical practice and professionalism, and an ambassador of research and innovation. For those who had the good fortune to work with, and get to know John, he was one of the great charismatic personalities in dentistry in recent times.

John began his exceptional career as a dental student at Guy's Hospital, winning many prizes including the prestigious Newland Pedley prize and medal. While a house surgeon to Sir William Kelsey Fry, John was encouraged to develop an interest in research by Professor Martin Rushton, under whose guidance John published his first paper, reporting odontoblast aspiration in dentinal tubules. At around the same time, John was a Surgeon Lieutenant in the Royal Navy Volunteer Reserve, serving with his fellow Guy's man Tony Naylor, later Professor of Preventive Dentistry at UMDS.

Once established as a private practitioner in the West End of London, John McLean returned to Guy's as a part-time demonstrator in conservative dentistry, prior to moving to the Eastman Dental Institute to pursue his interest in applied dental materials science. An MDS on the development of ceramic oxide reinforced dental porcelain preceded a DSc in 1978. This work underpinned a lifetime zeal for new knowledge and understanding in dental materials science; however, the quest was always for breakthroughs of immediate clinical and practical relevance.

Subsequent to being appointed Clinical Consultant to the Laboratory of the Government Chemist, John, together with Dr Alan Wilson, introduced glass-ionomer cements to dentistry. This development opened up many new exciting possibilities, and established a new field of research and development in dental materials science. Arguably, it is this aspect of John's work which has had the greatest impact. Such is the quality and significance of John's two volume work entitled The science and art of dental ceramics that it will increasingly come to be viewed as a classic text in prosthodontics.

In his presidential address to the BDA in 1994, John called for the injection of funds into research, postgraduate education and the dental manufacturing industry to realise enormous potential in the UK for innovation in dental materials science and related areas. Prophetically, he also talked of the weakening effect of amalgam techniques on tooth structure, the need to preserve tooth tissues and the benefits of using adhesive resins and minimally invasive procedures. His often quoted remark that "there is
Obituaries should be submitted by email to Kate Maynard at k.maynard@nature.com.

All submitted obituaries should be 350 words maximum in length (apart from obituaries for past presidents of the BDA where the length should be 700-800 words) Content of the obituary is down to the individual author, and the approval of the family should be given for the obituary prior

to submission to the $B D J$.

no better filling material than natural tooth tissue' should be emblazoned on the minds of generations of dentists to come. In his valedictory address, John was no less controversial, emphasising the plight of fellow practitioners caught in the so-called treadmill of drill and fill dentistry of the time.

John always had time to answer questions after his thought-provoking lectures and to encourage young colleagues to realise whatever opportunities dentistry held for them. This was always achieved with great charm and in John's inimitable style.

It is of no surprise that John was the recipient of many honours and awards. Subsequent to having been appointed an OBE in 1978, he was the recipient of the John Tomes Prize for research, among many other awards. To his great pleasure only months before his death, the American Prosthodontic Society bestowed on him the Society's coveted Golden Medallion.

John's immense accomplishments did not detract from his family life, nor prevent him pursuing other diverse interests. Diana, his wife, who to John's great sadness predeceased him in 1999, and his four daughters who survive him, were never far from John's thoughts. Whenever time permitted, John tended his magnificent garden, played golf and indulged in his eclectic range of interests, including fine wines and gourmet food.

John McLean was one of the great men of dentistry and the profession is much poorer for his loss. John can rest in peace in the knowledge that he made an important difference, served his beloved country, and upheld the highest standards in his chosen profession of dentistry.

NHFW, HWP 